\title{
The Variation of Trace Elements in Steenkool Coal Formation, Bintuni Basin, West Papua, Indonesia
}

\author{
Ahmad Helman Hamdani ${ }^{1}$, Johanes Hutabarat ${ }^{2}$ \\ ${ }^{1,2}$ University of Padjadjaran, Indonesia
}

\begin{abstract}
This study analyses of trace elements distribution in coal samples from Steenkool Formation in Bintuni Basin, West Papua. The term, "trace elements in coal," refers to as those elements with concentration below 0.1 wt. \% (1,000 ppm) in coal that are generally considered to be inorganic he ash content and depositional environment were controlling the amount of trace elements concentration. The trace elements, calcium and magnesium have the greatest organic affinities, whereas, Mn, Mg and Ca have affinities with the carbonates.
\end{abstract}

Keywords: Trace element, ash contents, depositional environment, coal, Steenkool Formation, Bintuni basin

\section{Introduction}

The trace elements are defined as those elements with concentration below 0.1 wt. \% (1,000 ppm). On coal utilization, although trace elements concentration only in the parts-per-millions (ppm) range; several elements have significant impact. The chalcophile elements such as As, Cd, $\mathrm{Hg}, \mathrm{Pb}$, and $\mathrm{Se}$ can give significant environmental hazard which should be releasing during coal combustion [1, 2, 3]. Other elements of halogens group such as $\mathrm{Cl}$ and $\mathrm{F} \mathrm{V}$ can make some corrosion in boiler $[4,5]$. However, the existence of trace elements can be positively impact; the elements of $\mathrm{Ge}, \mathrm{Zn}, \mathrm{U}, \mathrm{Au}$, may contribution of economic value byproduct. The concentration of trace elements for identified depositional environment.

The Bintuni Basin is located in the Bird's Head Area The eastern part West Papua. The research is in Horna village is located in northern part of the basin (Figure 1)

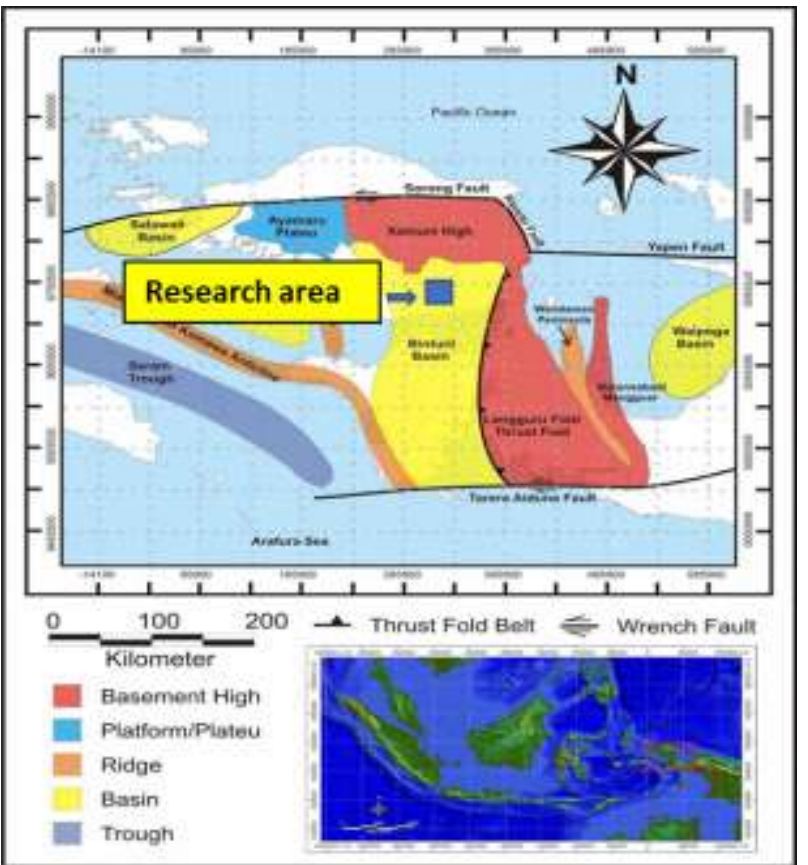

Figure 1: Location of research area in Horna District, Bintuni basin, West Papua
According to the Ransiki Sheet Geological Map (1989), the research area is composed of sedimentary rocks from various formations; which the sequence from old to young rocks are as follows: Klasafet (Tmk), Formation, Steenkool Formation (Tqps, Tqsm), and the youngest is the Alluvium (Qa). Following the explanation of each of the formation (Figure 2)

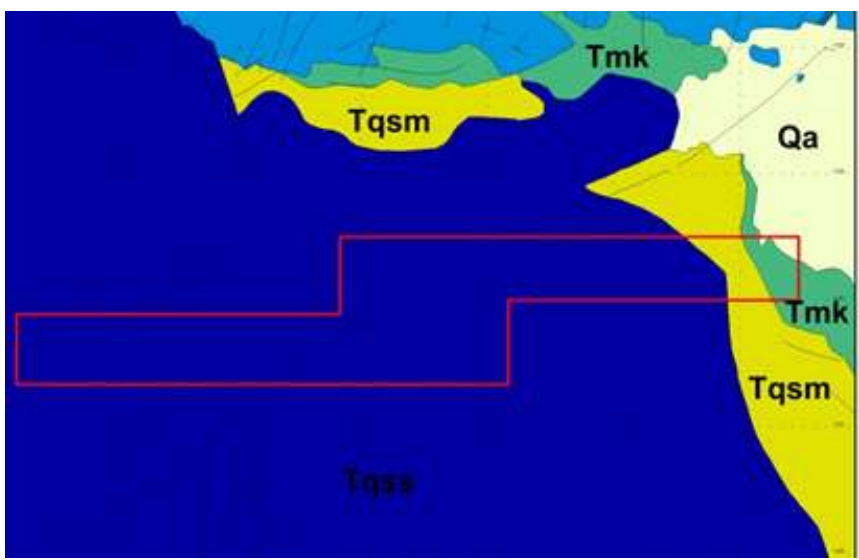

Figure 2: The geological map of Beimes Area, West Papua

The Klasafet Formation is an Early Miocene to Late Miocene Formation which has limited distribution in the eastern region of the study area; The Klasafet Formation consist of conglomerate, claystone, limestone, sandstone with lignite coal insertion. The Steenkool Formation is a Late Miocene to Pliocene, deposited in the western part of the research area. The Steenkool Formation is a coal bearing formation of Miocene to Pliocene age with a total thickness of about 500 $\mathrm{m}$; consisting of coal, siltstone, sandstone, conglomerate. Steenkool formations are deposited in delta environments [6, 7].

The aims and objectives of the work were to evaluate the trace element concentration and the factors controlling the distribution of trace element in coal samples.

\section{Data and Methods}

In this study, the preparation and identification of trace elements from coal were done in Succofindo Laboratory in

Volume 6 Issue 12, December 2017 


\section{International Journal of Science and Research (IJSR) \\ ISSN (Online): 2319-7064}

Index Copernicus Value (2016): 79.57 | Impact Factor (2015): 6.391

Jakarta with ASTM Standard ASTM D 6349-13; except for sulfur we use ASTM D-5016-08

\section{Result}

\subsection{Trace Element Concentrations}

Two (samples) coal samples from Steenkool Formation have been identified (Table 1)

Table 1: Concentrations of Trace Elements in coal

\begin{tabular}{|c|c|c|c|c|}
\hline \multirow{2}{*}{ Trace Elements } & \multicolumn{2}{|c|}{ Sample No } & \multicolumn{2}{c|}{ Sample No } \\
\cline { 2 - 5 } & HIM-1 & Unit & HIM-2 & Unit \\
\hline Silicon $(\mathrm{Si})$ & 96426.54 & $\mathrm{ppm}$ & 61568.44 & $\mathrm{ppm}$ \\
\hline Aluminum $(\mathrm{Al})$ & 37866.54 & $\mathrm{ppm}$ & 18375.71 & $\mathrm{ppm}$ \\
\hline Iron $(\mathrm{Fe})$ & 298021.51 & $\mathrm{ppm}$ & 207588.22 & $\mathrm{ppm}$ \\
\hline Titanium $(\mathrm{Ti})$ & 1506.37 & $\mathrm{ppm}$ & 525.38 & $\mathrm{ppm}$ \\
\hline Calcium $(\mathrm{Ca})$ & 38721.29 & $\mathrm{ppm}$ & 75404.47 & $\mathrm{ppm}$ \\
\hline Magnesium $(\mathrm{Mg})$ & 49731.80 & $\mathrm{ppm}$ & 141729.75 & $\mathrm{ppm}$ \\
\hline Potassium $(\mathrm{K})$ & 5690.89 & $\mathrm{ppm}$ & 1286.85 & $\mathrm{ppm}$ \\
\hline Sodium $(\mathrm{Na})$ & 1756.13 & $\mathrm{ppm}$ & 8071.99 & $\mathrm{ppm}$ \\
\hline Phosphorus $(\mathrm{P})$ & 636.06 & $\mathrm{ppm}$ & 86.91 & $\mathrm{ppm}$ \\
\hline Sulfur $(\mathrm{S})$ & 6.24 & $\mathrm{ppm}$ & 7.76 & $\mathrm{ppm}$ \\
\hline Manganese $(\mathrm{Mn})$ & 273.19 & $\mathrm{ppm}$ & 513.37 & $\mathrm{ppm}$ \\
\hline
\end{tabular}

The result of proximate, ultimate analyses for two samples were presented in table 2

Table 2: Proximate \& Ultimate Analyses, Moisture and Calorific Value of Coal samples

\begin{tabular}{|c|c|c|c|c|}
\hline \multirow{2}{*}{ Parameters } & \multicolumn{2}{|c|}{ Sample No } & \multicolumn{2}{|c|}{ Unit } \\
\cline { 2 - 3 } & HIM-1 & HIM-2 & \multicolumn{2}{|c|}{} \\
\hline Total Moisture & 2.0 & 5.6 & $\%$ & $\mathrm{ar}$ \\
\hline Moisture in Analysis & 1.6 & 2.1 & $\%$ & $\mathrm{adb}$ \\
\hline Ash & 3.0 & 1.7 & $\%$ & $\mathrm{adb}$ \\
\hline Volatile Matter & 44.9 & 47.2 & $\%$ & $\mathrm{adb}$ \\
\hline Fixed Carbon & 50.5 & 40.0 & $\%$ & $\mathrm{adb}$ \\
\hline Total Sulfur & 2.48 & 0.22 & $\%$ & $\mathrm{adb}$ \\
\hline GCV & 7,889 & 7,780 & $\mathrm{Kcal} / \mathrm{Kg}$ & $\mathrm{adb}$ \\
\hline NCV & 7,551 & 7,192 & $\mathrm{Kcal} / \mathrm{Kg}$ & $\mathrm{adb}$ \\
\hline Carbon $(\mathrm{C})$ & 77.93 & 77.63 & $\%$ & $\mathrm{adb}$ \\
\hline Hydrogen $(\mathrm{H})$ & 5.92 & 5.83 & $\%$ & $\mathrm{adb}$ \\
\hline Nitrogen $(\mathrm{N})$ & 1.93 & 1.94 & $\%$ & $\mathrm{adb}$ \\
\hline Oxygen $(\mathrm{O})$ & 8.74 & 12.66 & & \\
\hline
\end{tabular}

Note: GCV: Gross calorific value

NCV: Net calorific value

\subsection{Discussion}

Based on the ASTM coal classification, all the coals sample are classified as bituminous High Volatile B. The concentration of trace element from two samples showing the differences.

The contents of trace elements of $\mathrm{Si}, \mathrm{Al}, \mathrm{Fe}, \mathrm{Ti}, \mathrm{K}$ and $\mathrm{P}$ were decrease as the ash contents in coal are decreases too (see Table1 and 2). The ash contents in HIM-1 is higher than HIM-2. Therefore, most of the trace element content in HIM1 is high than in HIM-2, except Mn, Ca, Na, S and Mg. Due the chemical alteration during coalification processes in basin some trace elements can remobilize and precipitated as authigenic minerals. The silicate detrital mineral was filled the depositional basin during coalification. The good correlation between trace element concentration $(r=0.85)$ indicate that most of trace elements are still remain in the coal basin despite remobilization [4]. The elements of not decreasing in concentration with the ash content are related with organic affinities $(\mathrm{Ca}, \mathrm{Mg}$ ) and carbonate affinities i.e., $\mathrm{Ca}, \mathrm{Mn}, \mathrm{Mg}$ [8].

The iron (Fe) concentration in coal samples shown a highest concentration comparing to other elements (> 200,000 ppm) indicate that depositional environment has a low Eh. The second highest trace element concentration is calcium $(\mathrm{Ca})$, this is related with the carbonate mineralization of the oldest carbonate rock below the Steenkool Formation.

The silica is believed derived from originally contained within the plants [9]. The source of the element may be related to the Kemum High that existed to the north.

\section{Conclusion}

The concentration of trace element within the coal in Steenkool Formation in the Beimes District, Bintuni Basin, West Papua are controlling by the ash content and be related to depositional environments.

Trace element concentration was related with the ash content. Increasing the ash content should be following the increasing of $\mathrm{Si}, \mathrm{Al}, \mathrm{Fe}, \mathrm{Ti}, \mathrm{K}$ and $\mathrm{P}$. The different affinities element to organic, carbonates materials make the $\mathrm{Mn}, \mathrm{Ca}, \mathrm{Na}, \mathrm{S}$ and Mg not increasing

The depositional environment has low Eh due to highest iron $(\mathrm{Fe})$ content in coal samples.

\section{References}

[1] Robert B Finkelman, Trace Elements in Coal Environmental and Health Significance, Biological the Trace Element Research, v. 67, pp. 197-204, 1999

[2] Farshid Vejahati, ZhengheXu, Rajender Gupta, Trace elements in coal: Associations with coal and minerals and their behavior during coal utilization - A review, Fuel, v. 89, pp. 904-911, 2010

[3] R. B. Finkelman, Modes of occurrence of potentially hazardous elements in coal: level of confidence, Fuel Process. Technol. 39, pp. 21-34, 1994.

[4] Harold J Gluskoter, Mineral Matter and Trace Elements in Coal, Advances in Chemistry, v. 141, pp. 1-22, 1975

[5] P. Chu and D. B. Porcella, Mercury stack emissions from U. S. electric utility power plants, in Mercury as a Global Pollutant, D. B. Porcella, J. W. Huckabee, and B. Wheatley, eds., Kluwer, Dordecht, pp. 135-144 (1995).

[6] Chevallier, B., and Bordenave, M. Contribution of Geochemistry to The Exploration in The Bintuni Basin, Irian Jaya. Proceedings Indonesian Petroleum Association, pp. 339-460, 1986

[7] Pieters, P.E., A. Sufni Hakim and S. Atmawinata. 1990. Geological Mapping, Ransiki Sheet, Irian Jaya.

[8] Finkelman, R. B. "Proceedings," Basic Coal Science Workshop, Houston, TX; Energy Resources Co., Inc.: Cambridge, ;pp. 69-90, 1982

\section{Volume 6 Issue 12, December 2017




\section{International Journal of Science and Research (IJSR) \\ ISSN (Online): 2319-7064}

Index Copernicus Value (2016): 79.57 | Impact Factor (2015): 6.391

[9] Renton, J.J., Cecil, C.B., Stanton, R., and Dulong, F. In 'Carboniferous Coal Short Course and Guidebook, v. 3" (A.C. Donaldson, M.K. Presler, and J.J. Renton, eds.), AAPG Seminar, pp. 57-101, 1980.

Volume 6 Issue 12, December 2017

www.ijsr.net

Licensed Under Creative Commons Attribution CC BY 